\title{
EKSPLORASI MIKROBA EPIFIT, ENDOFIT DAN RIZOSFER DARI BERBAGAI SUMBER PADI GOGO DI KECAMATAN KULAWI KABUPATEN SIGI
}

\section{EXPLORATION OF EPIFIT, ENDOFIT AND RIZOSPHERE MICROBA FROM VARIOUS GOGO RICE SOURCES IN SUBDISTRICT KULAWI SIGI}

\author{
Jumardin $^{1^{*}}$, Fathurrahman ${ }^{2}$, Indrianto Kadekoh ${ }^{2}$, Andi Ete ${ }^{2}$ \\ ${ }^{1}$ Program Studi Agroteknologi, Fakultas Pertanian, Universitas Alkhairaat, \\ Jl. Diponegoro No. 39 Palu 94221, Indonesia \\ ${ }^{2}$ Program Studi Agroteknologi Fakultas Pertanian Universitas Tadulako, Palu, Indonesia
}

\begin{abstract}
ABSTRAK
Eksplorasi yang dilakukan pada area filosfer (daun) maupun area rizosfer (akar) pada tanaman padi gogo untuk mendapatkan jenis mikroba yang memiliki potensi yang dapat dimanfaatkan sebagaisumber pupuk hayati seperti, mikrob penambat $\mathrm{N}_{2}$, mikrob pemacu tumbuh tanaman atau mikrob pelarut fosfat serta yang berperan sebagai musuh alami. Penelitian dilakukan dengan metode survei lokasi. Penentuan letak lokasi dilakukan dengan cara sengaja (Purposive sampling), yakni lokasi tanaman padi gogo yang dibudidayakan petani di Kecamatan Kulawi. Hasil penelitian menunjukkan bahwa Telah disolasi mikroba epifit dan endofit dan rizosfer masing-masing 10 isolat. Uji morfologi menunjukkan perbedaan warna, bentuk, elevasi, tepi, tekstur dan ukuran ukuran dan Uji pewarnaan menunjukkan bahwa bakteri memiliki bentuk sel Coccus, Bacill, Diplococcus dan Semi- Bacillus
\end{abstract}

Katakunci: mikroba epifit, endofit dan Rizosfer, padi gogo

\section{ABSTRACT}

Exploration carried out in the filosphere area (leaves) and rhizosphere area (roots) in upland rice plants to get the type of microbes that have potential that can be utilized as biological fertilizer sources, such as $N_{2}$ fastening microbes, plant growth microbes or phosphate solvent microbial as well as those acting as natural enemies. The research was conducted by location survey method. Determination of location is done by purposive sampling, which is the location of upland rice cultivated by farmers in Kulawi District. The results showed that 10 isolates were isolated from epiphytic and endophytic microbes and endophytes. Morphological tests showed differences in color, shape, elevation, edge, texture and size and the coloring test showed that the bacteria had Coccus cell forms, Bacill, Diplococcus and Semi-Bacillus.

Keywords: epiphytic microbes, endophytes and Rizosphere, upland rice

\section{Pendahuluan}

Eksplorasi yang dilakukan pada area filosfer (daun) maupun area rizosfer (akar) pada tanaman padi gogo untuk mendapatkan jenis mikroba yang memiliki potensi yang dapat dimanfaatkan sebagai sumber pupuk hayati

\footnotetext{
${ }^{*}$ Penulis Korespondensi

E-mail: jumardin22@gmail.com

Telp: +62-85240935584
}

seperti, mikrob penambat $\mathrm{N}_{2}$, mikrobpemacu tumbuh tanaman atau mikrob pelarut fosfat serta yang berperan sebagai musuh alami.Peningkatan kesuburan tanah yakni penggunan agen hayati. Agen hayatiadalah mikroba yang diberikan untuk meningkatkan pengambilan hara oleh tanaman dari dalam tanah atau udara.

Bakteri epifit dan endofit dapat diisolasi dari permukaan dan jaringan tanaman yang steril atau diekstraksi dari jaringan tanaman bagian dalam. Secara khusus, bakteri masuk ke jaringan 


\section{Jurnal $\boldsymbol{C a g r o t e c h ~}_{8}$ (2) 73-78}

melalui jaringan yang berkecambah, akar, stomata, maupun jaringan yang rusak (Zinniel et al., 2002).

Keragaman bakteri bisa dilihat dari berbagai sudut pandang seperti ; morfologi, fisiologi, dan genetik. Tiap-tiap habitat yang berbeda memberikan keragaman yang berbeda pula(Amanda, 2010). Contoh habitat yang sering dihuni oleh bakteri adalah daun. Tiap tanaman mempunyai daun yang berbeda, baik dari segi bentuk, ukuran, maupun eksudat yang dikeluarkannya. Menurut Vorholt (2012) bahwa perbedaan tersebut menyebabkan bakteri yang menghuninya juga berbeda, walaupun pada tanaman tertentu ditemukan populasi bakteri yang sama.

Berdasarkan beberapa uraian di atas, maka telah dilakukan penelitian dengan judul potensi mikrob filosfer dan rizosfer dari berbagai sumber padi gogo di Kecamatan Kulawi Kabupaten Sigi Provinsi Sulawesi Tengah.

\section{Metode Penelitian}

Penelitian ini dilaksanakan di Laboratorium Hama dan Penyakit Tanaman serta Agroteknologi Universitas Tadulako.

Tahapan dilakukan dengan metode survei lokasi. Penentuan letak lokasi dilakukan dengan cara sengaja (Purposive sampling), yakni lokasi tanaman padi gogo yang dibudidayakan petani di Kecamatan Kulawi. Sampel daun (sumber bakteri epifit dan endofit) dan tanah (sumber daun rizosfer) yang diambil dari berbagai sumber tanaman padi gogo (Steel \& Torrie 1980).

\section{Hasil dan Pembahasan}

\section{Karakteristik Lokasi}

Secara geografis Kecamatan kulawi berada pada posisi $1^{0} 20^{\prime} 18^{\prime}$ ' $-1^{0} 43^{\prime} 22$ '" LS dan $119^{\circ} 4^{\prime} 04^{\prime}$ ' $-120^{\circ} 07^{\prime} 53$ ' 'BT. Jumlah curah hujan antara 28,00-130,00 mm/tahun. Kelembapan antara $73,10-8,80 \%$, penyinaran matahari antara. $45,70-69,10 \%$, suhu antra $26,7-27,7^{\circ}$ C. Kecamatan Kulawi merupakan salah satu kecamatan di Kabupaten Sigi Propinsi Sulawesi Tengah yang memiliki batas-batas wilayahyakni, sebelah Utara berbatasan dengan Kecamatan gumbasa dan Kecamtan Lindu, sebelah Timur berbatasan dengan Kabupaten Poso, sebelah Selatan berbatasan dengan Kecamatan Kulawi Selatan dan Kecamatan Pipikoro, sebelah Barat berbatasan dengan Sulawesi Barat. Kecamatan Kulawi berada bearada pada bagian selatan wilayah Kabupaten Sigi, dengan jarak $62 \mathrm{Km}$
e-ISSN : 2621-7236

p-ISSN : 1858-134X

dari Ibu Kota Kabupaten. Untuk sampai di ibu kota kecamatan dan jika musim kemarau beberapa desa dapat ditempuh dengan kendaraan roda empat dan ada lima desa yang hanya dapat ditempuh dengan kendaraan roda dua /motor ojek melalui jalan setapak namun pada musim hujan hanya bisa dilalui berjalan kaki.

\section{Topografi}

Berdasarkan elevasi Kecamatan Kulawi pada umumnya merupakan daerah pegunungan dan berada pada sepanjang aliran Sungai Lariang yang terletak pada ketingggian 500-1000 m di atas permukaan laut. Kemiringan tanah cukup curam yakni berkisar $60 \%-70 \%$ dan bahkan ada yangmencapai $80 \%$. Persentase ketinggian desadesa di atas permukaan laut yakni $0-500 \mathrm{~m} \mathrm{dpl}$ sebanyak 21, $42 \%$ dan 501-100 d dpl sebanyak $78,58 \%$ (BPS, 2014).

\section{Letak Pengambilan Sampel}

Pengambilan sampel dilakukan secara menyebar pada 10 titik ladang petani yang telah melakukan usaha budidaya padi ladang di Kecamatan Kulawi. Pengambilan sampel epifit dan endofit pada bagian daun yang secara sengaja diambil dari tanaman padi gogo sedangkan sampel rizosfer pada bagian daerah perakaran tanaman,. Dimana pada setiap sampel memiliki karakteristik lokasi yang beragam baik secara topografi, titik koordinat dan ketinggian tempat.

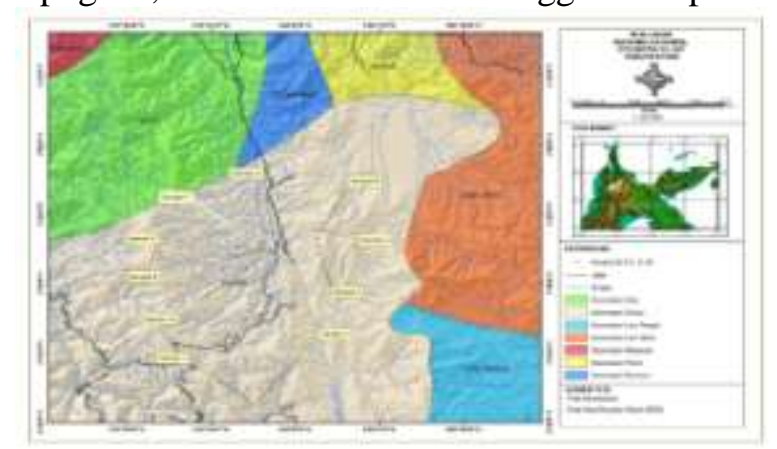

Gambar 1. Peta lokasi pengambilan sampel

Isolasi bakteri filosfer (epifit, endofit) dan rizosfer

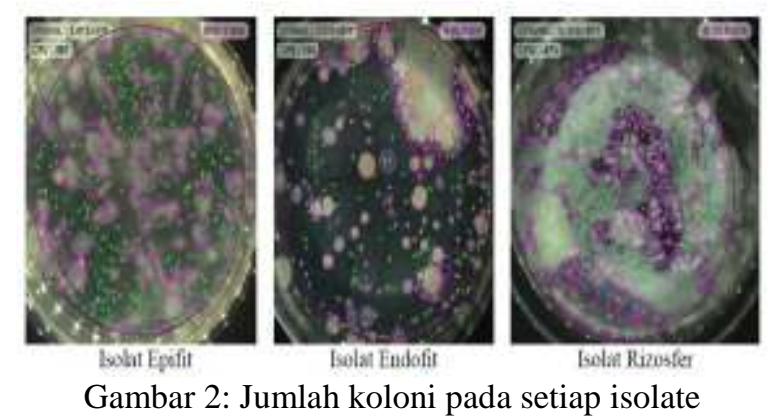


Isolasi bakteri yang bersumber dari tanaman padi gogo, pada setiap sampel bakteri rizosfer, epifit dan endofit masing-masing 10 isolat sehingga secara keseluruhan telah terdapat 30 isolat dan pada pengenceran yang sama yakni $1^{-9}$. Pada setiap isolattelah memiliki jumlah bakteri yang berbeda. Keberagaman jumlah bakteri pada setiap isolat dapat disebabkan perbedaan habitat pada setiap sumber sampel (Gambar 2).

Lingkungan merupakan habitat untuk semua mkhluk hidup, termasuk mikroorganisme. Mikroorganisme merupakan bakteri yang hidup secara bebas dan berkoloni dengan jumlah mencapai milyaran sel bakteri. Menurut Saraswati $d k k .$, (2007), bakteri adalah organisme prokariotik bersel tunggal dengan jumlah kelompok paling banyak dan dijumpai di tiap ekosistem terestrial. Rao (1994) menyatakan bawa bakteri memegang peranan penting dalam pembentukan tanah, dekomposisi bahan organik penyedia unsur hara, berasosiasi secara mutualistik dengan tanaman, namun ada juga sebagai penyebab penyakit tanaman.

Kelimpahan bakteri tersebut mendorong untuk melakukan isolasi pada berbagai bagian tanaman. Bagian permukaan daun terdapat bakteri epifit, bagian jaringan daun terdapat bakteri endofit dan bagian daerah perakaran yang telah menempel tanah pada bulu akar terdapat bakteri rizosfer. Isolasi bakteri epifi, endofit dan rizosfer telah ditumbuhkan pada media nutrient agar (NA) yang merupakan media yang tidak selektif dan setiap isolat disuspensikan dengan menggunakan pengenceran bertingkat hingga $10^{-9}$ untuk kesemua isolat.

Hasil penelitian menunjukkan bahwa isolasi bakteri yang telah dilakukan memberikan jumlah populasi yang berbeda pada setiap sampel. Hal ini dikarenakan adanya perbedaan sumber pengambilan isolat. Sebagaimana yang telah dikemukakan oleh Amanda (2010) bahwa tiap-tiap habitat yang berbeda memberikan keberagaman yang berbeda dan lebih lanjut oleh Vorholt (2012) bahwa perbedaan tersebut yang menyebabkan bakteri yang menghuninya juga berbeda, walaupun pada tanaman tertentu telah temukan populasi bakteri yang sama.

Hasil penelitian menunjukkan bahwa terdapat perbedaan jenis bakteri yang hidup secara berkoloni dalam satu habitat. Dengan adanya perbedaan jumlah populasi dan jenis pada setiap isolat, maka harus dilakukan pemisahan atau pemurnian pada masing-masing koloni sesuai dengan perbedaan kenampakan morfologi secara makroskopis.

\section{Uji Morfologi}

Pengamatan morfologi yang dilakukan bertujuan mengetahui warna, bentuk, elevasi tepi, tekstur dan ukuran koloni. Uji morfologi pada setiap isolat yang telah dimurnikan (Tabel 1)

Tabel 1. Uji morfologi pada setiap isolat yang telah dimurnikan

\begin{tabular}{|c|c|c|c|c|c|c|}
\hline \multirow{2}{*}{ Kode Sampel } & \multicolumn{6}{|c|}{ Morfologi } \\
\hline & warna & bentuk & elevasi & tepi & tekstur & ukuran \\
\hline S8EPa & Putih susu & irreguler & convex & entire & Halus mengkilat & large \\
\hline $\mathrm{S} 8 \mathrm{EPb}$ & crem & circular & convex & entire & Kering bubuk & small \\
\hline S9ENa & $\begin{array}{l}\text { Krem } \\
\text { kemerahan }\end{array}$ & irreguler & raised & lobate & Halus mengkilat & moserate \\
\hline S9ENb & Putih susu & irreguler & raised & entire & Halus mengkilat & small \\
\hline S9ENc & Putih krem & filamentous & raised & serrate & Halus mengkilat & moserate \\
\hline S9Ra & Putih susu & irreguler & convex & lobate & Halus mengkilat & moserate \\
\hline $\mathrm{S} 9 \mathrm{Rb}$ & krem & irrguler & convex & entire & Kering bubuk & small \\
\hline S9Rc & kemerahan & irreguler & convex & entire & kasar & moserate \\
\hline S9Rd & Putih kuning & rhizoid & raised & serrte & kasar & moserate \\
\hline
\end{tabular}

\section{Uji Morfologi pada Setiap Jenis Bakteri}

Isolat murni dari mikroba Filosfer (epifit, endofit) dan rizosfer sebanyak sembilang telah dilakukan pengujian karakter secara morfologi (Tabel 2) Capuccino dan Sherman (1992) menyebutkan bahwa karakterisasi morfologi bertujuan untuk mengamati baik morfologi koloni maupun morfologi sel bakteri pada isolat bakteri yang telah lolos seleksi. Menurut Krairitthichai dan Thongwai, 2005) bahwa pemerikasaan uji karakter morfologi koloni bakteri yang berbeda dihgunakan uji degradasi selulosa dengan mengamati bentuk tepian, elevasi dan warna koloni. Mikroorganisme yang ditumbuhkan pada media yang bervariasi akan menunjukkan penampakan makroskopis yang berbeda-beda pada pertumbuhannya. Perbedaan 


\section{Jurnal Agrotech 8 (2) 73-78}

ini disebut dengan karakteristik kultur, yang digunakan sebagai dasar untuk memisahkan mikroorganisme dalam kelompok taksonomik (Sabdaningsih $d k k ., 2013$ ).

Berdasarkan hasil pengamatan secara morfologi pada kesembilan jenis bakteri (Tabel 2) kesembilan bakteri yang diisolasi telah memiliki karakter morfologi yang berbeda-beda. Perbedaan morfologi setiap isolat pada penelitian ini sejalan dengan pernyataan Cappucino and Sherman (1987) dalam Zahara dkk., (2018)
e-ISSN : 2621-7236

p-ISSN : 1858-134X

bahwa pada umumnya bentuk koloni bakteri berbentuk circular, irregular, filamentous, rhizoid. Elevasi berbentuk raised, convex, flat, umbonate, crateriform. Tepian yang berbentuk entire, undulate, filiform, curled dan lobate.

\section{Uji Pewarnaan Gram}

Pewarnaan gram merupakan salah satu cara yang dilakukan untuk mengetahui sifat bakteri yang gram positif atau gram negatif (Tabel 2).

Tabel 2. Uji pewarnaan gram pada bakteri

\begin{tabular}{|c|c|c|c|c|c|}
\hline \multirow{2}{*}{$\begin{array}{c}\text { Kode } \\
\text { sampel }\end{array}$} & \multirow{2}{*}{ Gambar } & \multirow{2}{*}{ Warna } & \multirow{2}{*}{ Bentuk } & \multicolumn{2}{|c|}{ Pewarnaan Gram } \\
\hline & & & & Positif & Negatif \\
\hline $\mathrm{S} 8 \mathrm{EPa}$ & & Ungu muda & Coccus & + & \\
\hline $\mathrm{S} 8 \mathrm{EPb}$ & & Ungu muda & Coccus & + & \\
\hline
\end{tabular}

Kemerahan Bacill

S9ENa

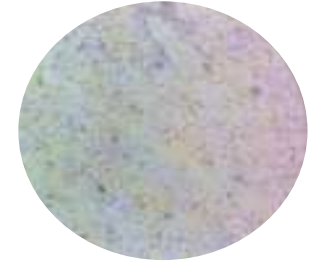

S9ENb

S9ENc

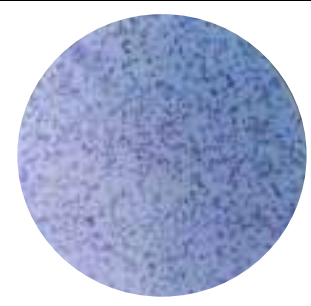

Biru nuda Diplococcus

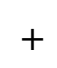




\begin{tabular}{|c|c|c|c|}
\hline S9Ra & Merah muda & $\begin{array}{c}\text { Semi- } \\
\text { Bacillus }\end{array}$ & - \\
\hline $\mathrm{S} 9 \mathrm{Rb}$ & Merah muda & Bacillus & - \\
\hline S9Rc & Merah muda & Bacillus & - \\
\hline S9Rd & Merah muda & Bacillus & - \\
\hline
\end{tabular}

\section{Uji Pewarnaan Pram}

Salah satu cara yang masih diperlukan dalam taksonomi bakteri menurut Campbell et al. (2000) diantaranya adalah pewarnaan Gram, cara ini digunakan untuk memisahkan anggotaanggota domain. Bakteri Gram positif memiliki dinding sel yang lebih sederhana, dengan jumlah peptidoglikan yang relatif banyak. Dinding sel bakteri gram-negatif memiliki peptidoglikan yang lebih sedikit dan secara struktural lebih kompleks.

Hasil pengamatan morfologi sel yaitu dengan cara pewarnaan Gram pada setiap isolat. Kesembilan isolat menunjukkan bahwa terdapat gram positif-negatif dengan warna dan bentuk yang berbeda-beda (Tabel 2). Hasil penelitian menunjukkan bahwa mikroba epifit memiliki warna ungu merah dan bentuk coccus dengan bakteri gram positif. Mikroba endofit memilki warna kemerahan dan bentuk yang bacill, coccus dan diplo-coccus dengan bakteri gram positifnegatif. Struktur dinding sel bakteri Gram positif. Mikroba rizosfer memiliki warna merah muda dan bentuk semi bacill dan bacill.

Hasil penelitian menunjukkan bahwa adanya perbedaan komponen pada dinding sel dimana bakteri gram positif mampu mempertahankan zat warna utama yakni Gention Violet. Penyusun dinding sel pada bakteri gram positif berbeda ngan bakteri negatif dimana bakteri gram positif sebagian besar petidoglikan sedangkan bakteri gram negatif sebagian besar dinding selnya tersusun oleh lipid. Menurut Barazandeh (2008) bakteri Gram positif memiliki peptidoglikan sebesar $90 \%$ serta mempunyai komponen spesifik pada dinding selnya berupa asam teikoat dan asam lipoteikoat.

Hasil penelitian menunjukkan bahwa kebanyakan isolat yang diisolasi merupakan bakteri gram negatif hal ini disebakan kondisi pengambilan sampel yang memiliki tingkat kesuburan tanah yang rendah tidak kompleks dalam memproteksi pertahanan dari gangguan fisik dan pathogen dalam jaringan inang. Menurut Sutedjo $d k k$ (1996), selain bahan mineral dan bahan organik keadaan iklim daerah, vegetasi yang tumbuh, reaksi yang berlangsung dan kadar kelembaban mempengaruhi populasi mikroorganisme di dalam tanah. Dilanjutkan Alexander (1977), jumlah mikroorganisme tanah dipengaruhi oleh berbagai kondisi seperti : kerapatan vegetasi, temperatur, sumber energi dan kelembaban. 


\section{Jurnal Agrotech 8 (2) 73-78}

\section{Kesimpulan}

Setelah melaksanakan penelitian maka dapat disimpulkan bahwa :

1. Telah disolasi mikroba epifit dan endofit dan rizosfer masing-masing 10 isolat

2. Uji morfologi menunjukkan perbedaan warna, bentuk, elevasi, tepi, tekstur dan ukuran ukuran.

3. Uji pewarnaan menunjukkan bahwa bakteri memiliki bentuk sel Coccus, Bacill, DiplococcusdanSemi- Bacillus

\section{Daftar Pustaka}

Alexander, M. 1977. Ecology of nitrogen fixing organisms. In Ayanaba, A. and P.J. Dart (eds). 1977. Biological Nitrogen Fixation in Farming Systems of the Tropics. New York: John Wiley and Sons

Amanda J. Redford, Robert M. Bowers,Knight R, Linhart Y, Fierer N., 2010. The Ecology of the Phyllosphere: Geographic and Phylogenetic Variability in the Distribution of bacteria on tree leave. Environmental Microbiology 12(11): 2885-2893

Badan Pusat Statistik 2014. Statistik Indonesia 2013/2014. Jakarta (ID) :Badan Pusat Statistik. 529p.

Barazandeh, N. 2008. Microbiology Titles. Springer-Verlag Berlin Heidelberg. Media ,pp 9-11.

Campbell, N.A., Reece J.B. and Mitchell, L.G., 2002. Biology, $5^{\text {th }}$ ed. Alih Bahasa: Wasmen Manalu. Erlangga. Jakarta.

Capuccino dan Sherman, 1987. Microbiology: A Laboratory Manual. The Benjamin Cummings Publishing Company Inc. California USA.
e-ISSN : 2621-7236

p-ISSN : 1858-134X

Krairitthichai, S \& Thongwai, N., 2005. Isolation and Screening for Cellulase Producing Bacteria, In 34th Congress on Science and Technology of Thailand, Thailand

Rao, S.M.S. 1994. Mikroorganisme Tanah dan Pertumbuhan Tanaman. UI Press. Jakarta. Edisi ke dua.

Saraswati, R, Santosa, E \& Yuniarti, E, 2010, Organisme Perombak Bahan Organik, diakses 5 juli 2016, http://balittanah.litbang.deptan.go.id/ pupuk10.pdf.

Sutedjo, M,M., 1996. Mikrobiologi Tanah. Rineka Cipta. Jakarta.

Steel RGD, Torrie JH., 1980. Principle and Procedures of Statistic. A Biometrical Approach. 2 Ed. New York (US):McGraw-Hill. 633p.

Vorholt JA. 2012. Microbial Life in the Phyllosphere. 828:Dec. Vol. 10 www.nature.com/reviews/micro.

Macmillan Publishers Limited. All rights reserved.

Sabdaningsih A., Budiharjo A., Kusdiyantini E., 2013. Isolasi Dan Karakterisasi Morfologi Koloni Bakteri Asosiasi Alga Merah (Rhodophyta) Dari Perairan Kutuh Bali. Jurnal Biologi, Volume 2 No 2, April 2013 Hal. 11-17.

Zinniel, D.K., P. Lambrecht, N.B. Harris, Z. Feng, D. Kuczmarski, P. Higley, C.A. Ishimaru, A. Arunakumari, R.G. Barletta, and A.K. Vidaver. 2002. Isolation and characterization of endophytic colonizing bacteria from agronomic crops and prairie plants. Applied and Environmental Microbiology, 68: 2198-2208. 